\title{
COASTAL DEFENCE EVALUATION: AN SPRC APPROACH
}

\author{
Dominic E. Reeve ${ }^{1}$, Jose M. Horrillo-Caraballo ${ }^{1}$, Andrew Fox ${ }^{2}$, Dave Simmonds ${ }^{2}$, Sum H. \\ Kwan ${ }^{3}$, Shunqi Pan $^{4} \&$ Deborah Greaves ${ }^{2}$
}

\begin{abstract}
In this paper, we show how the methodology based on the Source-Pathway-Receptor-Consequence (SPRC) approach can be used to identify the risks of flooding and erosion. The methodology is applied to the Teign Estuary in Devon, UK to define the linkages between physical loads (waves, tides), sea defences, areas liable to flooding and the impacts of flooding.
\end{abstract}

Keywords: flood risk; SPRC; Teign Estuary

\section{INTRODUCTION}

\section{Background}

Coastal areas are vital economic hubs in term of population, industry, trade and tourism to mention some key sectors. As economies grow or develop the asset base at risk will increase, while climate changes will amplify the likelihood of extreme events, as well as accelerate habitat decline. The European project THESEUS, which this study forms a part, aims to examine the application of innovative combined coastal mitigation and adaptation technologies to promote a low-risk coast for humans as well as healthy coastal habitats, reflecting continuous changes due to sea level rise and climate changes. Developing an approach to coastal flood risk assessment in line with the EU Floods Directive (EC, 2007) is a key feature of this aim. An overarching aim of the THESEUS project is to apply ideas and methods to selected study sites; learning from these experiences to develop innovative "climate proof technology". A key element of the project is integrating the social and ecological aspects of the flood system into more traditional risk analysis, as well as developing a framework within which a diverse range of management options (engineering, social and ecological) can be assessed.

\section{The concept of risk}

In the mid-1990s the UK insurance industry recognized that they needed to reassess the scale of the liabilities they were insuring against flooding. They commissioned a study to assess the risk of coastal flooding in England and Wales. A detailed discussion of the methodology can be found in Reeve \& Burgess (1994), and discussion of mapping procedures in Burgess \& Reeve (1994) and Maddrell et al (1995, 1996). Further development of a national scale assessment methods were presented by Meadowcroft et al (1996). This raised the profile of flood risk assessment but concentrated on the physical and economic attributes of the problem. Recognition of the need for integration of flood risk research and policies across disciplines, and across administrative and political boundaries has resulted in a large number of regional and national scale flood risk studies in Europe and elsewhere (e.g., Evans et al. 2004, Mokrech et al. 2008, FLOODSite Consortium 2009, FRMRC2 2010). All these studies commonly treat flood risk is understood to be the combination of the probability of a flood event occurring and the evaluation

of the consequences, while the "failure" of a sea defence is defined as the unwanted flow of water across the line of the defence crest. Risk in engineering is usually expressed as a function of the probability of a hazard (an event or a load on a structure) and its consequence:

$$
\text { Risk }=\mathrm{P}(h) \mathrm{C}
$$

where $\mathrm{P}(h)$ refers to the probability of a hazard and $\mathrm{C}$ refers to the consequence. Probabilities are often considered on an annualised basis, (eg. the distribution of annual maxima), while consequences will typically be measured in monetary terms. Thus risk as defined in Equation (1) has units of a rate of expenditure. For assessing the purely physical aspects of flood risk Equation (1) is well accepted.

\footnotetext{
${ }^{1}$ College of Engineering, Swansea University, Singleton Park, Swansea, Wales, SA2 8PP, UK

${ }^{2}$ School of Marine Science and Engineering, Plymouth University, Drake Circus, Plymouth, PL4 8AA, UK.

${ }^{3}$ Civil Engineering and Development Department, Hong Kong

${ }^{4}$ School of Engineering, Cardiff University, The Parade, Cardiff, Wales, CF24 3AA, UK.
} 
However, when wider aspects are included, such as ecological or socio-economic consequences of flooding, the picture becomes more difficult. This is particularly the case where Equation (1) demands a purely monetary approach to assessing damage whereas socio-economic and ecological disciplines often deal in less quantified measures. This raises difficulties when attempting to develop and implement integrated approaches to flood risk management. It was partly as a result of these difficulties that the source-pathway-receptor-consequence, (or SPRC), concept was developed. The strength of this approach, which is described in the next section, is not particularly in its analytical or technical characteristics but rather, in its role as providing a mechanism through which experts from different disciplines communicate and reach a common understanding of the different aspects of the flood risk problem.

\section{THE SPRC APPROACH}

The Source - Pathway - Receptor - Consequence (SPRC) was described as a conceptual model by Gouldby and Samuels (2005). This model has been adopted from environmental pollution where it is used to describe the flow of contaminants from a source, through a conducting pathway to a receptor (Holdgate, 1979). There is no rigorous definition of the SPRC approach and its role remains as a conceptual model.

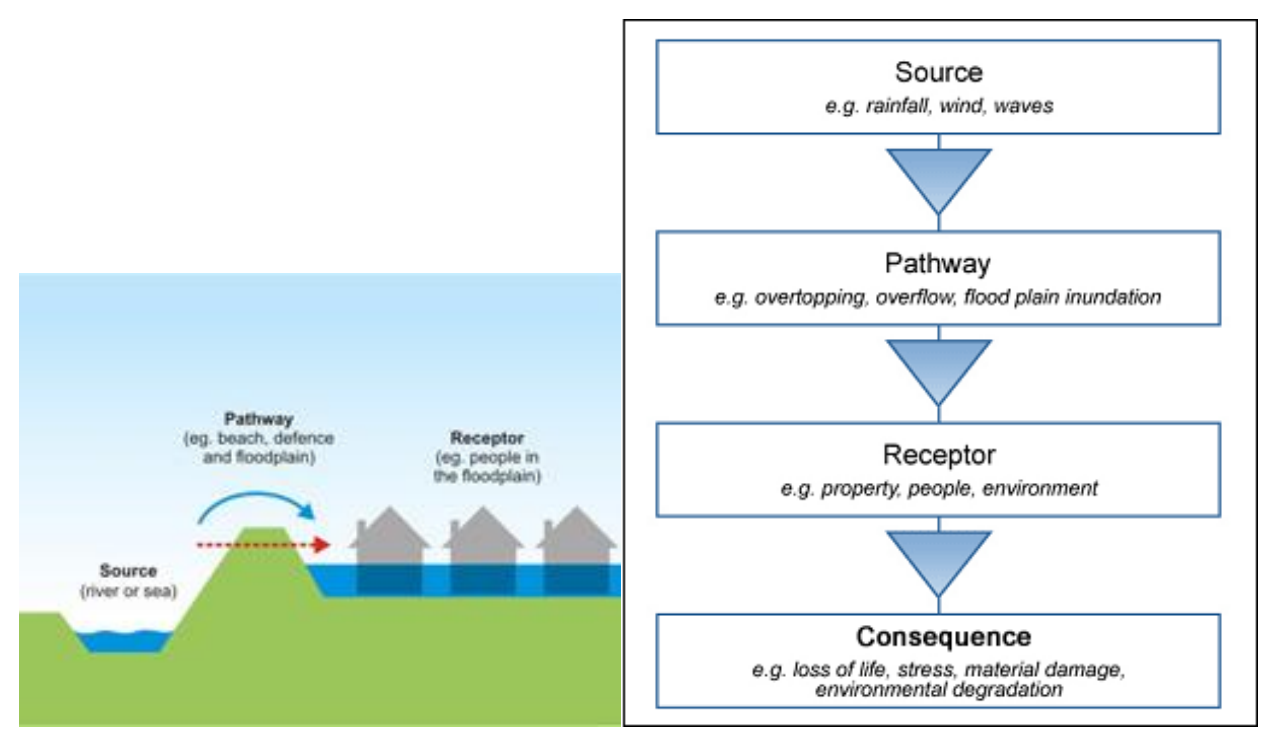

Figure 1. Examples of a source-pathway-receptor-consequence diagram for flood risk. Left panel Environment Agency (2012), right panel Floodsite (2012).

Figure 1, (lefthand panel) provides a pictorial representation of the source-pathway-receptor concept while the righthand panel is a diagrammatic representation that also includes the subsequent element 'consequence'. In both cases the concept is strictly linear. In practice, river and coastal floodplains are 2 or 3 dimensional and hence receptors can be affected by more than one pathway and source.

\section{THE STUDY SITE}

\section{The THESEUS project study sites}

As part of the THESEUS project a number of sites across Europe have been selected for specific study. In particular, the following elements have been undertaken at each site:

- Analysis of historic and future extremes of sources (waves, water levels, river flows, rainfall, etc);

- An SPRC analysis

- Assessment of ecological and socio-economic factors

- Investigation of novel site-specific flood defence techniques 
The study sites are shown in Figure 2. The remainder of this paper is concerned with the Plymouth to Exe Estuary, (or South Devon), study site.

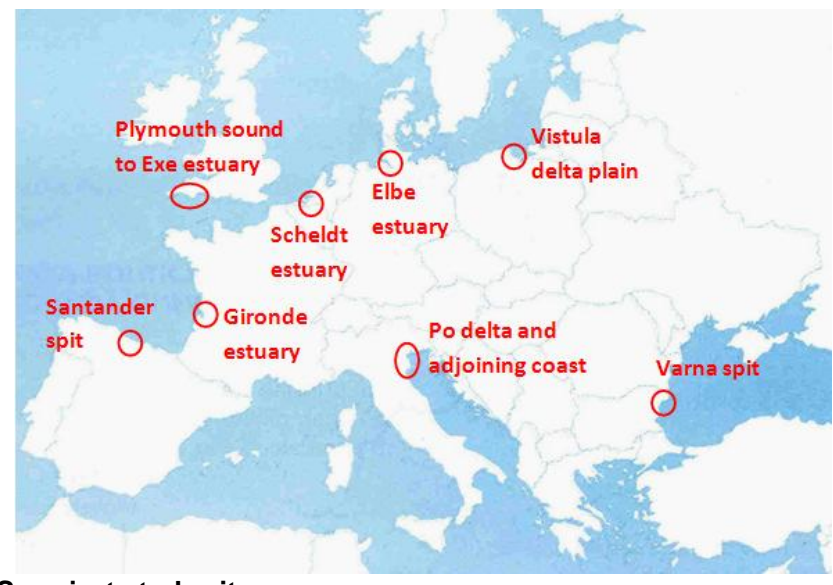

Figure 2. The THESEUS project study sites.

The study site: Plymouth Sound to Exe Estuary is located in southwest England, see Figure 3(a-b), encompassing a $100 \mathrm{~km}$ stretch of coastline bordered by the English Channel. The site is one of the most diverse coastal settings in Europe and incorporates a range of habitats from exposed rocky and shingle coast to sheltered mud of flooded valleys or 'rias' together with densely populated urbanised and industrial zones of Plymouth Sound and Torbay. Therefore, it is a unique and representative site to involve the complex coastal and estuarine processes; interaction between coastal defence structures and coastal morphology; and significant economic, social and environmental impacts.

Within the study site, the research is focused on the Teign Estuary Figure 3(c). A major modifier of the coastline is the railway line, which started by the South Devon Railway Company, running from Exeter St Davids to Teignmouth in 1846 and later extended to Newton Abbot. Since then the railway have been modernised and operated to the present time. The railway line occupies considerable stretches of coastal frontage (Exeter to Dawlish to Teignmouth to Newton Abbot). Coastal defence work to protect the railway line has modified coastal processes. Pressures also include physical disturbance, for example by trampling, dredging, fishing gear, land claim and adjacent coastal development through the construction of sea defences and potential for changes in the hydrological regime.

The study site also features a range of important and sensitive marine habitats including grazing meadows, saltmarshes, mud flats, rocky and sandy seabeds, together with important biogenic habitats. Intertidal and marsh habitats are important for numerous species of birds, insects and plants. Collectively these habitats support a diverse flora and fauna including rare and endangered species. The estuary also supports commercially important species including oysters, cockles and crabs grazing marshes are important for cattle. Within the adjoining coastline are Slapton Ley, Torbay and the Exe Estuary. The Exe estuary is a RAMSAR site (wetland of international importance) Site of Special Scientific Interest, a Site of Special Protection (EC Birds Directive). Torbay, is one of 28 areas in England designated by English Nature as a Sensitive Marine Area. Its sheltered aspect, unusual geology and warm climate mean that underwater, just as on land, the area is host to an exceptionally diverse range of habitats. Seagrass and mussel beds, present throughout the area are important habitats and potential ecosystem engineers which stabilise the substratum and provide an important source of organic matter, and a surface for attachment by other species. This shelter makes them important nursery areas for flatfish and, in some areas, for cephalopods. 


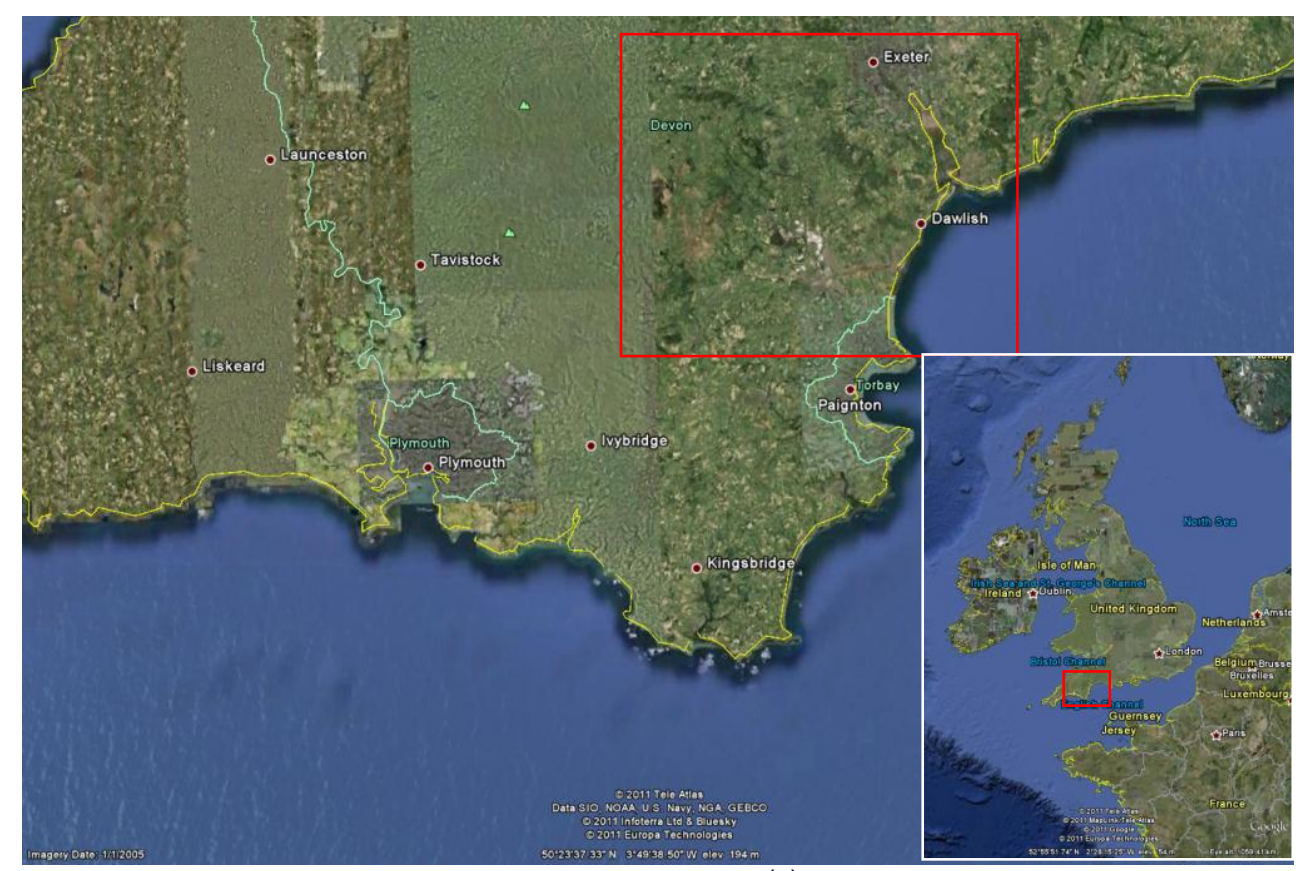

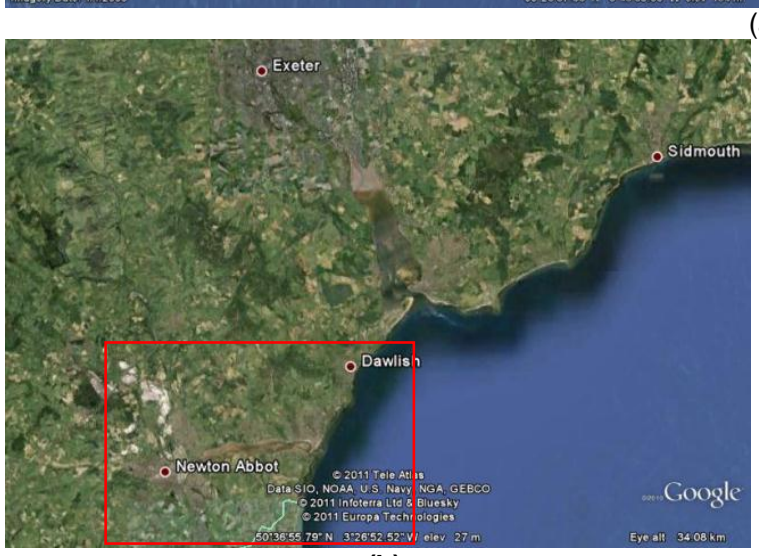

(b)

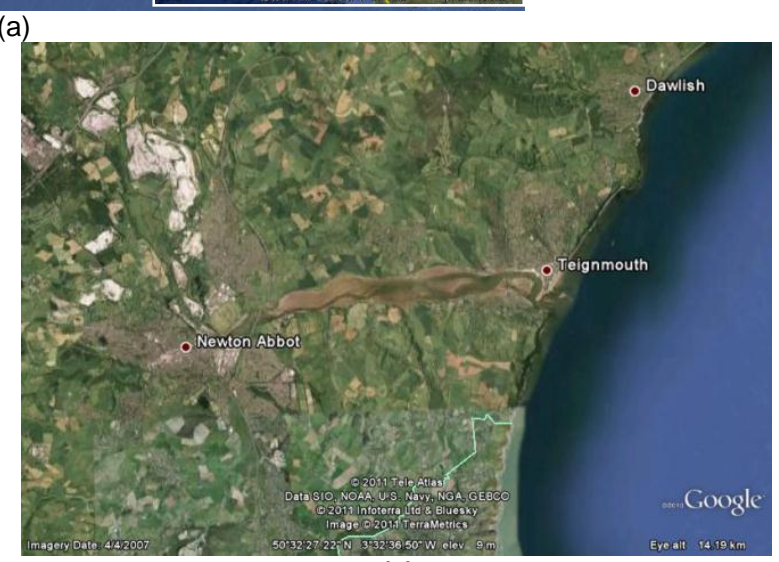

(c)

Figure 4. The study site - Plymouth Sound to Exe Estuary. (a) whole site; (b) Exe and Teign Estuaries; (c) Teign Estuary.

The spring tidal range at the study site is approximately $3.8 \mathrm{~m}$, with the maximum tidal current up to 3.0 $\mathrm{m} / \mathrm{s}$, while the tidal current in the Lyme bay is relatively weak, of $0.5 \mathrm{~m} / \mathrm{s}$. The waves in the area are predominately the swell waves from Atlantic in the south-west direction, with yearly mean significant wave height of $2.0 \mathrm{~m}(\max 4.0 \mathrm{~m})$ and for 1 in 50 year return period, the mean significant wave height is $2.7 \mathrm{~m}$ (max $5.3 \mathrm{~m})$.

The River Teign arises on Dartmoor at a height of 520m AOD (above Ordinance Datum at Newlyn) and flows in a south-easterly direction towards the Teign Estuary and the sea. The catchment covers an area of $550 \mathrm{~km}^{2}$. The principal sub-catchments are the Rivers Lemon and Bovey and the Aller Brook. The estuary is also influenced by the large river flow. The River Teign flows through a diversity of landscapes and habitats, ranging from open moorland (Dartmoor) to ancient woodland, improved pasture land and broad valleys, before finally meeting its floodplain and the estuary.

The Teign Estuary is approximately $9 \mathrm{~km}$ in length and less than $1 \mathrm{~km}$ wide at its widest Point and is defined as a ria by JNCC (1997). It is one of South Devon's most valuable assets. The mouth of the Estuary is marked by a permanent spit "the Point", on the north bank at Teignmouth extending southwest, and the red cliffs at Shaldon to the south. 


\section{RESULTS}

To develop a consistent perspective of the flood risks and consequences for the Teign Estuary it was necessary to create a suitable consensus across a wide range of disciplines. In the past, this has been one of the biggest difficulties in this type of exercise. Here, we used the SPRC concept to engage with a large range of interested parties and stakeholders to develop a pictorial representation of the estuary, the main sources of flooding, the pathways and receptors. This was deliberately set at a relatively coarse level to avoid unnecessary discussion about engineering or ecological technicalities. Thus, pathways are at the scale of defence lengths (maybe up to a kilometer or more long) along which the structure conditions are fairly uniform, although of course there may well be small variations about this. Similarly, receptors have been defined by investigating digital terrain models, derived from LIDAR measurements, to describe 'basin scale' areas that are liable to flood if the fronting defence is overwhelmed. Within this, some further refinement has been undertaken based on land-use as defined in the CORINE database.
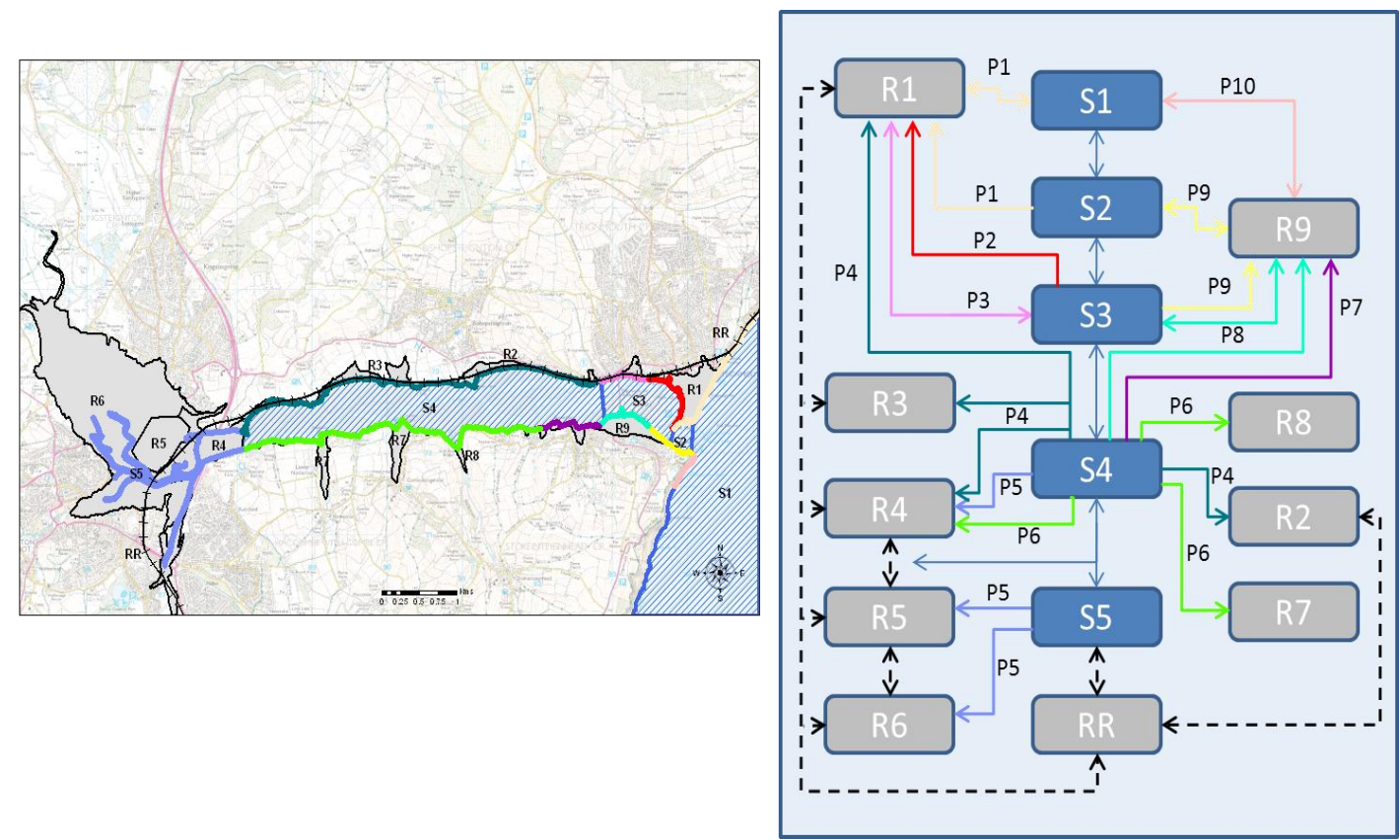

Figure 4. The SPRC diagram for the Teign Estuary. Lefthand panel shows the geographic distribution of sources, (Sn), pathways (colour coded), and receptors (Rn). Righthand panel shows the SPRC diagram with linkages between the sources and receptors.

Figure 4 shows, (lefthand panel), a pictorial version of the SPRC model for the Teign Estuary. In this, flood areas, (receptors), are numbered as $\mathrm{R} n$ where $n$ is a number. Sources are shown as $\mathrm{S} n$ and pathways are coloured lines running along the line of the defence crest. The righthand panel is a diagrammatic representation of the same thing but the links between specific sources and receptors is explicitly shown. At a glance one may see from this type of diagram which receptors are at risk from multiple sources and pathways, while the map-type presentation of the lefthand panel provides a clearer picture of the geographical extent and configuration.

Such maps can then provide a useful basis on which to introduce additional information on land use and ecology. As an example, the ecological habitats map for the Teign Estuary is shown in Figure 5. This shows the wide variety of habitats present in the estuary and their relationship (sometimes equivalence to) the receptors in Figure 4. 


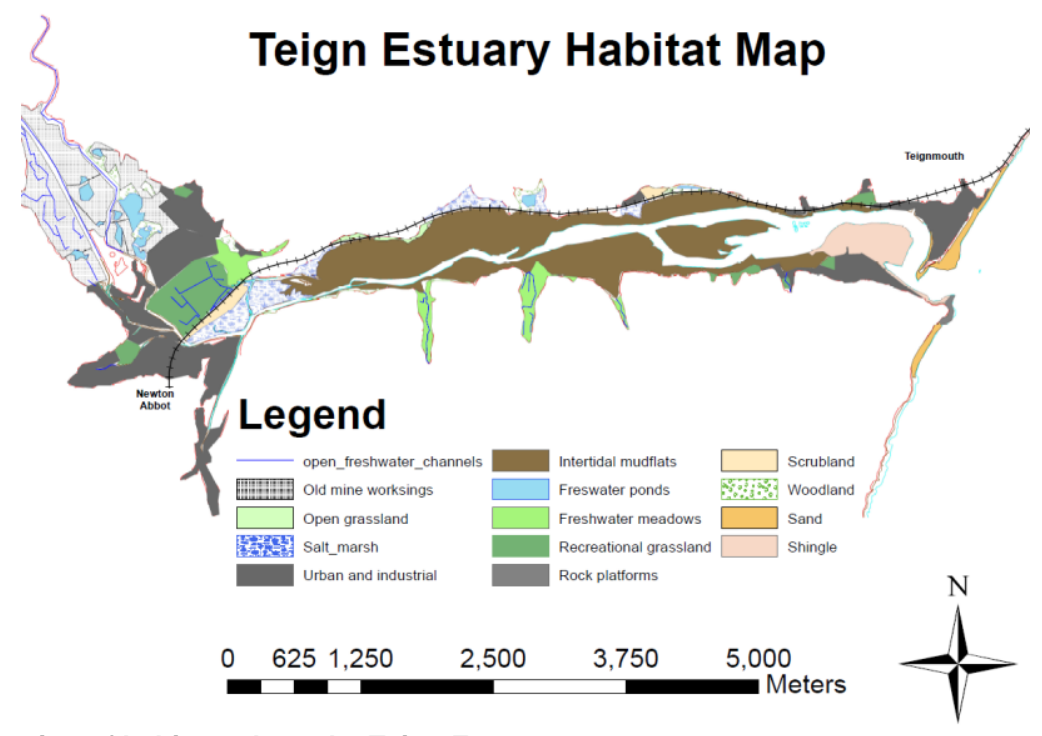

Figure 5. Classification of habitats along the Teign Estuary.

Clearly to define the physical hazard requires an analysis of the sources. That is, computing extreme values of water levels and wave conditions. In a companion paper, (Horrillo-Caraballo et al 2012), the data and methods used to define extreme conditions in and around the estuary are described. Here, we show the results of an inundation calculation under the 1 in 200 year event for the period 2070-2100AD. This involved computing the volume of water that would overtop the defences during a storm and then calculating how this volume of water would spread across the landward terrain.

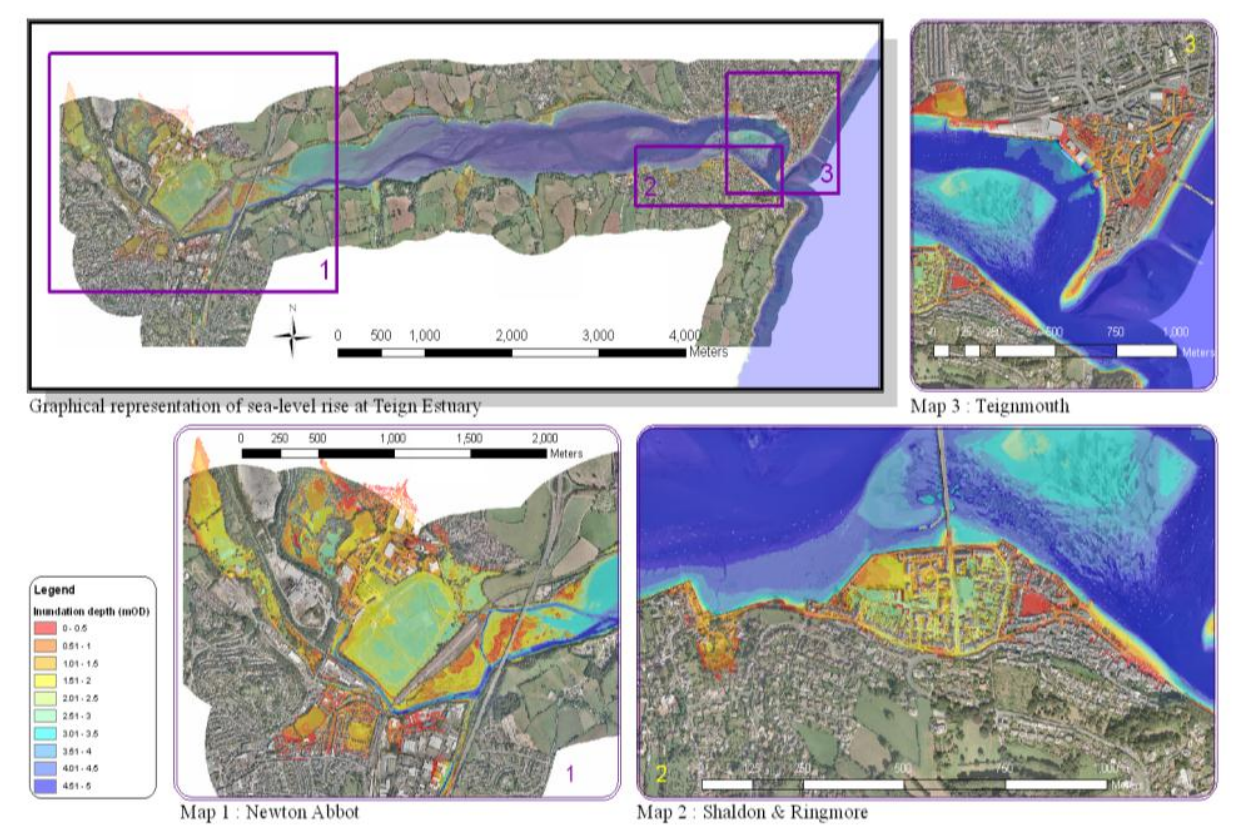

Figure 6. Flood depth maps under the 1 in 200 year condition in the 2070-2100AD scenario. Top left shows the whole estuary, top right the Estuary entrance, bottom left Newton Abbot and bottom right the towns of Shaldon and Ringmore. Red indicates a flood depth of between 0 and $0.5 \mathrm{~m}$ while dark blue indicates a depth between 4.5 and $5 \mathrm{~m}$. Contour intervals are in $0.5 \mathrm{~m}$ intervals.

There are clearly areas of ecological value and socio-economic value that are at risk. By combining the information on the extremes of the sources (waves and water levels) with that on defences, ecological habitats and socio-economics/land use allows an integrated picture of the nature of the risk to be developed. 


\section{CONCLUSIONS}

Coastal flood systems are complex, multi-scale and involve aspects from many scientific and engineering disciplines. Adaptation of methods developed in structural reliability theory (eg. Melchers 1999) has provided some useful techniques for assessing flood risks arising from physical processes, (see, for example, Reeve 2010). However, the wide range of inter-disciplinary flood risk studies that have been or are being conducted in Europe is a reflection not only of the complexity of these flood systems but also the importance of managing flood risk. The original 1D SPR concept is incapable of describing inter-connected flood systems. Nevertheless, nearly all applications of the SPR have taken a one-dimensional representation of the coastal flood system, until its extension to a two-dimensional model by Narayan et al. (2012).

In this paper we have outlined the application of the SPRC concept to a site on the southern coast of the UK, the Teign Estuary. The approach has been to acknowledge the 2D nature of the linkages between courses, pathways and receptors. It is superior to the 1D approach in this respect. It is also clear that the SPRC concept can be a flexible and powerful tool for building a comprehensive shared understanding about the flood system among stake-holders. Importantly, stakeholders found that the completed form of the model highlighted the key system characteristics, assumptions and issues being investigated, emphasising the soundness of the 2D SPR as a conceptual basis for further quantitative analyses.

\section{ACKNOWLEDGMENTS}

The support of the European Commission through the project "Innovative Technologies for safer European coasts in a changing climate" (THESEUS), Contract 244104, FP7.2009-1, www.theseusproject.eu, is gratefully acknowledged.

\section{REFERENCES}

Burgess K.A. \& Reeve D.E., 1994. The development of a method for the assessment of sea defences and risk of flooding. Proc $29^{\text {th }}$ MAFF Conference of River and Coastal Engineers, Loughborough, pp. 5.3.1-5.3.12.

Environment $\quad$ Agency, $2012 . \quad$ http://learning.environmentagency.gov.uk/courses/FCRM/FloodRiskManagement/section2 2.html, sited accessed 6/9/2012.

European Parliament and Council of the European Commission 2007. Directive 2007/60/EC on the assessment and management of flood risks (23 October 2007), Official Journal of the European Union. Brussels, Belgium; European Union.

Evans, E. et al., 2004. Foresight Future Flooding: Scientific summary: Volume I - future risks and their drivers. Office of Science and Technology, London.

FLOODSite Consortium, 2009. Methodology for a dss to support long-term flood risk management planning, H R Wallingford.

FLOODSite Consortium, 2012. http://www.floodsite.net/html/faq2.htm, site accessed 7/9/2012.

FRMRC 2, 2010. Flood Risk Science and Management (Ed, G Pender \& H Faulkner), WileyBlackwell, 544pp.

Horrillo-Caraballo, J.M., Pan, S., Reeve, D.E., Simmonds, D.J., Greaves, D. \& Fox, A., 2012. Modelling extreme wave events (present and future scenarios) in southwest England, Proc. $33^{\text {rd }}$ ICCE, Santander, Spain.

Maddrell, R.J., Mounsey, C. \& Burgess, K.A., 1995. Coastal flooding: Assessing the risk for the insurance industry, ICE Conference, 1995, Brighton, UK

Maddrell, R.J., Fleming, C.A. \& Mounsey, C., 1996. Assessing coastal flood risks. Proc $25^{\text {th }}$ ICCE, Orlando, USA, Vol. IV, p4339-4352.

Meadowcroft, I.C., Reeve, D.E., Allsop, N.W.H., Diment, R.P. \& Cross,J.C., 1996. Development of new risk assessment procedures for coastal structures, in Advances in Coastal Structures and Breakwaters (Ed J E Clifford, Thomas Telford, London, p6-46.

Melchers, R.E., 1999. Structural reliability analysis and prediction, $2^{\text {nd }}$ Edition, J Wiley \& Sons, Chichester, pp437. 
Mokrech, M. et al., 2008. Regional impact assessment of flooding under future climate and socioeconomic scenarios for East Anglia and North West England. Climatic Change, 90(1): 31-55.

Narayan, S. et al., 2012. A holistic model for coastal flooding using systems diagrams and the source pathway - receptor (SPR) concept. Nat. Hazards Earth Syst. Sci, 12: 1431-1439.

Reeve, D. E., 1998. On coastal flood risk, ASCE J. Waterway, Port, Coastal \& Ocean Engineering, Vol. 124, No.5, p219-228.

Reeve, D.E., 2010. Risk and reliability: Coastal and hydraulic engineering, Spon Press, Abingdon, pp304. 